\title{
THE “FAR EASTERN HECTARE” FEDERAL ACT AS THE MEANS OF REDUCING THE DECLINE IN THE POPULATION OF THE FAR EASTERN FEDERAL DISTRICT OF THE RUSSIAN FEDERATION
}

For a long time, one of the main problems in modern Russia has been the decline in population of the Far Eastern Federal District (FEFD).

Despite the fact that the Far Eastern Federal District is the largest federal district of the Russian Federation (its area is 6,169,329 square kilometers, accounting for $36.08 \%$ of the area of the whole country), it's also the most poorly populated federal district of the country (a population of 1,946,969 people, that is only 1.2 people per square kilometer). ${ }^{1}$ What makes it the most sparsely populated federal district. However, the socio-economic changes of the 1990s have significantly changed the dynamics, directions and scope of migration flows in the far East, and most importantly - the motivation of migratory behavior. Natural losses of demographic potential was amplified by the significant outflow of the population, which not only reduced the level of the population, but have significantly reduced the share of the region in the total population of Russia (1989 to $5.4 \%$ in 1997 to $5 \%$ in 2007 to $4.6 \%)^{2}$

According to the National Population Census of the year 2002, on 9 October 2002, in the FEFD, there lived 6,692,865 persons, representing 4.61\% of the population of the Russian Federation. According to the all-Russia population census in 2010 , the population of the region is 6,293,126 people. Thus, in 8 years, the population decreased by 400 thousand of people. Currently, the depopulation process has slowed, but not stopped. ${ }^{3}$

1 А.Ю. Чмыхало, О перспективах реализауии кончепчии миграуионной политики российской федерачии в сибири и на дальнем востоке, http: / / cyberleninka.ru/article/n/o-perspektivah-realizatsiikontseptsii-migratsionnoy-politiki-rossiyskoy-federatsii-v-sibiri-i-na-dalnem-vostoke (accessed: 9.04.2017).

2 В.А. Ушакова, Аальневосточный федеральньгй округ: миграчионнье прочессь и перспективы их развитияhttp:/ / cyberleninka.ru/article/n/dalnevostochnyy-federalnyy-okrug-migratsionnyeprotsessy-i-perspektivy-ih-razvitiya (accessed: 9.04.2017).

3 Аекчия 24. Аальневосточный федеральный округ, http://studme.org/13370710/ekonomika/ dalnevostochnyy_federalnyy_okrug (accessed: 9.04.2017). 
Population reduction occurred due to both natural decline and migration outflow. In 1992-2007, natural depopulation amounted to 281 thousand persons $(22,9 \%$ of the total losses of the population). Major losses were the southern regions of the province (314,6 thousand people), and Sakhalin (41.9 thousand persons) and Kamchatka (8.3 thousand persons) region. In the Chukotka Autonomous district, an area with a strong influence of the national traditions, will remain the natural increase. The high natural increase characteristic of the Republic of Sakha (Yakutia), which is associated with a low share of pensioners in the age structure of the population, is $11 \%$ of the total population (Russia - 20,6\%). ${ }^{4}$

Government policy for the residents of the region always had a compensatory nature and was aimed, on the one hand, to smooth the negative impact of climatic, territorial and socio-geographical conditions of residence, and on the other hand, to attract population from other regions of the Russian Federation. The underlying increase in the income compensation payments in the form of benefits, the district coefficients and allowances to salaries in the pre-perestroika period has provided the far East higher growth rates of money income and wages compared to the average rates. Not undergone significant changes and additions to the system of material incentives in the region in the early 1990s was not effective. ${ }^{5}$

The process of depopulation in these regions of Russia is on the background of increased geopolitical importance, especially in connection with the prospect of opening a year-round navigation along the Northern sea route, beginning the development of subsoil on the Arctic shelf, Eastern Siberia and the Russian east. The involvement of local people in the operation will be impossible due to the lack of available labor resources. ${ }^{6}$

Migration processes have always played an important role in the life of the country and its regions, ensuring the development and settlement areas, redistributing population and labor resources. Thanks to the implementation of state measures for the accelerated development of the productive forces of the FEFD, the region for a long period of time has a steady population growth: from 1970 to 1989, the number in the far east increased by 2161 thousands.

However, the socio-economic changes of the 1990s have significantly changed the dynamics, directions and scope of migration flows, and most importantly, the motivation of migration behavior. Natural losses of demographic potential was amplified by the significant outflow of the population, which not only reduced the level of the population, but have significantly reduced the share of the region in the total population of Russia (1989 to 5.4\% in 1997 to 5\% in 2007 to 4.6\%). For the period 1992-2007, a loss of population amounted to 1228,8 thousand

\footnotetext{
В.А. Ушакова, Аальневосточныгй федеральныий округ... Ibidem.

6 А.Ю. Чмыхало, О перспективах реализачии...
} 
people. The population of Chukotka Autonomous Okrug decreased 2.5 times, Magadan Oblast lost more than 53\%, Sakhalin and Kamchatka Krai $-1 / 3$ of the population. Smaller losses were suffered by the Amur Oblast (14.5\%), and Jewish Autonomous Oblast (14.4\%), Primorsky (12.3\%), Khabarovsk (12.1\%) Krai. A significant influence on the formation of the balance of migration in both the northern and southern regions had a reduction and relocation of military units, leaving the population in connection with the collapse of the Soviet Union. ${ }^{7}$ The main directions of the domestic migration flows have become the areas to the west and south, while in previous periods the vectors of migration flows were directed to the east and north. The migration turnover in Russia in 1990, amounted to 4.26 million people. ${ }^{8}$

But actually, the current situation has some positive process. On the other hand the average life expectancy of the population of the FEFD in 2009 was 66 years, including men -60 years, women -72 years of urban population -67 years, the rural population -64 year. Which means that life expectancy of the county population is constantly growing in recent years, for 2004-2009, it increased by 3.6 years 9 .

\section{The far eastern hectare act}

In June of 2016, the federal act on "The peculiarities of providing citizens with land plots in federal or municipal ownership and located in the constituent territories of the Russian Federation within the Far Eastern Federal District, and on amendments to certain legislative acts of the Russian Federation" N 119- $\Phi 3$, so-called the "far eastern hectare act" was implemented ${ }^{10}$ designed to solve the demographic problems of the Far Eastern territories. It should be noted that such a law is quite a unique attempt to speed up the process of reducing depopulation in the region.

The law provides granting land plots. Over 145 million ha of land in the far East Region are waiting to be registered in ownership. In Khabarovsk region, there are 33 million ha (it is more than $40 \%$ of the land area in the region) available. The law

\footnotetext{
7 В.А. Ушакова, Аальневосточныгй федеральныгй округ...

8 Г.А. Батищева, Исследование внутренней миграчии в Pоссии, http:/ / cyberleninka.ru/article/n/ issledovanie-vnutrenney-migratsii-v rossii\#ixzz4QYG1WjiR (accessed: 9.04.2017).

9 И. Полонский, Аальневосточный гектар. Поможет ми новый закон освоить Аальний Восток?, https://topwar.ru/94851-dalnevostochnyy-gektar-pomozhet-li-novyy-zakon-osvoit-dalniyvostok.html (accessed: 9.04.2017).

10 Федеральный закон „Об особенностях предоставления гражданам земельных участков, находящихся в государственной или муниципальной собственности и расположенных на территориях субъъектов Российской Федерации, входящих в состав Аальневосточного федерального округа, и о внесении изменений в отдельные законодательные акты Российской Федерации" от 1.05.2016 N 119-Ф3.
} 
implies the possibility for citizens of the Russian Federation to use a single free plot up to 1 ha for a period of five years.

Foreigners can join the program, but cannot own the land until 5 years after they have immigrated to Russia. ${ }^{11}$

A group of 10 persons, regardless of the type of relationships between them, will be able to write an application on granting a plot, based on the fact that every citizen can get a site up to 1 ha to share. So in the future, Russians will be able to use more than 140 million ha in the far East. ${ }^{12}$

The law regulates the relations connected with the provision of land plots that are in state or municipal property and located on the territory of the Republic of Sakha (Yakutia), Kamchatka Krai, Primorsky Krai, the Khabarovsk Krai, the Amur Oblast, the Magadan Oblast, Sakhalin Oblast, Jewish Autonomous Oblast, Chukotka Autonomous Okrug for Russian citizens.

A citizen of the Russian Federation once on the basis of his statements, can have aa plot of land in free use for 5 years. This plot must be in state or municipal property and situated in the territory of one of the subjects of the Russian Federation, members of the FEFD. ${ }^{13}$

Before the expiry of the agreement on the uncompensated use of an estate plot, a citizen has the right to apply for registration of the ownership of this land (but not earlier than 6 months). ${ }^{14}$

The law establishes requirements for the contents of a statement of granting a land plot free of charge. Citizens should only establish the most important information about themselves and the land plot. So the procedure is pretty simple in the statement a person should enter the information about:

1) surname, name, patronymic, place of residence of the applicant and details of the identity document of the applicant;

2) name and location of the applicant (for a legal person), as well as the state registration number of record about the state registration of the legal entity in the unified state register of legal entities, taxpayer identification number;

3) cadastral number of the requested land plot;

11 И.Ю. Трофимов, А.В. ВАовенко, Основныге проблемьг при предоставлении земельных участков гражданам в рамках реализачии закона о "Дальневосточном Гектаре», "Ученые заметки ТОГУ" 2016, no. 4, pp. 397-400.

12 А.В. Завьялов, К.В. Аавринович, «Аальневосточныгй гектар» как продолжение Стольппинких реформ начала XX века, “Инновационные технологии в науке и образовании” 2016, по. 2 (6), pp. 352-357.

13 ГражАане РФ могут получить в свое безвозмездное пользование, собственность или аренду земельный участок площадью Ао 1 гектара на территории Аальневосточного федерального округа, http://www.consultant.ru/law/hotdocs/46326.html (accessed: 10.11. 2016).

14 Ibidem. 
4) the type of ownership for the land on which the applicant wishes to acquire land, if all land is specified by the applicant at multiple types of rights;

5) requisites of the decision on withdrawal of a land plot for state or municipal needs in case the land was granted in return of a land plot, seized for state or municipal needs;

6) the purpose of using.

After the verification of the application the authorized body not later than 20 days after receipt of the application prepare and draft a contract of uncompensated use of land, or adopt a decision to refuse to grant land (for the reasons specified in the law) or performs operations necessary for the formation of the land plot (in case the requested land will have to form).

To receive a plot, it is not required to move to a permanent residence in the far Eastern regions. The only requirement is to reclaim the land plot. In what way, the citizen could decide for himself. Nobody sets the destination of the land.

From October, all inhabitants of the regions could apply for the benefit, but only in the region of their residence. From February 2017, all citizens of the Russian Federation are allowed to do that.

Land can be used for free, any reclaim of the land which is not prohibited by Federal law.

A citizen must send to the authorized body a notification of the selected type of permitted use of the land plot. This notification must be done not later than one year from the date of the contract of uncompensated use of land. In the case that the contract of uncompensated use of land plot concluded with several citizens, such notification must be signed by all the citizens or their representatives. ${ }^{15}$

\section{Conclusions}

Of course it's too early to draw any conclusions because the law was adopted less than a year ago. However, the high interest of the public to the opportunity of having a hectare in FEFD should be noted.

In the Khabarovsk region from 1 October, residents of the region filed 718 (more than in any other region) applications accordingly to the requirements of the legislation. On their basis 184 contracts were prepared on which 102 ha have already been transferred to citizens. 92 land plot were granted before 1 October in the plot of the Amur district. All owners of the "far Eastern acres" in the region were already 194 people. ${ }^{16}$

15 А. Вильф, Выгдче «дальневосточного гектара» может мешать кадастровый вопрос, 29.04.2016, http:/ / ria.ru/society/20160429/1422936030.html (accessed: 10.09.2016).

16 О.А. Руднева, Анализ перспектив реализачии законопроекта "Аальневосточныий гектар", "Помитика. Экономика. Социальная сфера: Проблемы взаимодействия” 2016, no. 4, pp. 28-32. 
It should be noted that this is the only one of the existing programs for the development of the far-Eastern region. One of them is the "Socio-economic program of the development of the Far East and the Baikal region for 2016 and the planning period of 2017-2018," and the program "Socio-economic development of the Kuril Islands."

Therefore, the law on the "far eastern hectare" that met enthusiastic support in the State Duma and the President, at the same time raises many questions. First, the legal status of those lands is not very clear. Only after five years a citizen will be able to rent or buy the land. But who can guarantee that the state will not take this land back, despite the fact that people have invested time, effort, and money? Secondly, it confuses many and the provided land is $1 \mathrm{ha}$. For the construction of houses and construction of infield with garden hectares of land - more than enough. But for agricultural production it is an absolutely tiny area.

Important point - the issue of development of the necessary infrastructure. By signing the law, President Putin has demanded to allocate land where there is the opportunity to ensure the availability of a modern infrastructure. However, even in the European part of Russia, not all locations are provided with water supply, sewerage or, at least, have gas supply. The only kind of housing and communal infrastructure, existing everywhere is electricity. In addition, if the government intends to involve to the far East families with children, the question arises about the security of displaced persons available to kindergartens, schools, extracurricular educational institutions, clinics and hospitals. All of these institutions, of course, also need to be staffed, but the lack of pedagogical and medical staff - an acute problem for rural areas in the European part of Russia.

One more problem is that local population was very excited with the idea of allocating hectares of land. In particular, in Yakutsk in December 2015 was strike against the implementation of the Federal Act. ${ }^{17}$ The protests were caused by the fears of inhabitants of Yakutia, as a result of the distribution of the "far Eastern Hectare" act, the local population may remain without land. In April 2016, the residents of the Republic of Yakutia again requested not to distribute the action of the Act on the territory of the this Republic. ${ }^{18}$

However, despite the existing problems, we are sure that this Act has all possibilities to be able to positively influence the situation in the region. Of course good law needs to have a proper interpretation, but it is impossible to analyze the process of granting land plots because of the lack of experience.

17 А.М. Ильченко, Е.Р. Мясищева, Аальневосточный гектар» как инструмент решения проблемъз развития дальнего востока, "Инновационное развитие российской экономики” 2016, nо. 1, pp. 62-65.

18 А.В. Фадеева, Е.В. Астахов, А.А. Романенко, «Аальневосточныгй гектар» - новое в правовом регулировании, “Научные труды SWORLD” 2016, no. 45, pp. 70-73. 
STRESZCZENIE

\author{
USTAWA FEDERALNA O CECHACH ŚWIADCZENIA \\ OBYWATELOM DZIAEEK ZNAJDUJĄCYCH SIE \\ W PAŃSTWOWEJ LUB SAMORZĄDOWEJ NIERUCHOMOŚCI \\ JAKO ZABEZPIECZENIE PRAWNE ZMNIEJSZENIA \\ SPADKU POPULACJI DALEKOWSCHODNIEGO OKREGU \\ FEDERALNEGO FEDERACJI ROSYJSKIEJ
}

W artykule omówiono treść ustawy federalnej O cechach świadczenia obywatelom działek znajdujących się w państwowej lub samorządowej nieruchomości i znajdujących się na terenach Federacji Rosyjskiej, wchodzących w skład Dalekowschodniego Okręgu Federalnego. Przeanalizowano bazę zasobową Dalekowschodniego Okręgu Federalnego, jego sytuacje ekonomiczną oraz główne problemy rozwoju. Poddano analizie znaczenie przyjęcia ustawy dla rozwoju społeczno-gospodarczego Dalekowschodniego Okręgu Federalnego. 